\title{
Android-Based Network Services Application Learning Media for Vocational High Schools
}

\author{
https://doi.org/10.3991/ijim.v15i20.23745
}

Dony Novaliendry ${ }^{1,2}$, Asrul Huda $^{1}$, Debi Sanita ${ }^{1(\bowtie)}$, Dino Adi Putra ${ }^{1}$, Marsinah Dewi Feiyska Nasution ${ }^{1}$, Rezi Septiardi Putra ${ }^{1}$, Rizka Novri Hidayati ${ }^{1}$

${ }^{1}$ Universitas Negeri Padang, Padang, Indonesia

${ }^{2}$ National Kaohsiung University of Science and Technology, Kaohsiung, Taiwan

debisanita@outlook.com

\begin{abstract}
Digital and communication technology has developed in combination with globalization to ensure quick connectivity and distribution of information. In particular, the quality of education is one of the education challenges that have become a target for urgent solutions. From the various conditions and potentials that exist, efforts that can be made concerning quality improvement in schools are to develop a student-oriented learning system (children center) and facilitate student's needs for learning needs that are challenging, active, creative, innovative, practical, and fun by developing and apply learning based on Information and Communication Technology. This research was generated using the media development method, which refers to Four-D development, which consists of four stages: Define, Design, Develop, and Disseminate, carried out in high school. Vocational class XI Computer and Network Engineering. In this study, the test subjects were students of class XI Computer and Network Engineering at SMK Negeri 8 Padang. The three validator's assessment as a whole, the validator test assessment of AndroidBased Learning Media is $94.28 \%$. The validity level can be interpreted as being Very Valid to use. Overall, the practicality assessment of Android-Based Learning Media as a learning resource is $88.46 \%$, so that the level of practicality can be interpreted as Very Practical to use. The evaluation of Android-Based Learning Media's effectiveness of $90.86 \%$, so that the level of significance can be interpreted as Very Good for use.
\end{abstract}

Keywords - android, learning media, methods, student, network service technology

\section{Introduction}

Education is not just providing knowledge or values or practicing skills. Education functions to develop what the students have the potential and actual. Empty education glasses must be filled from the outside, but they must have something, more or less has 
developed (actualized) or is still a bud (potential). Law Number 20 of 2003 concerning Education implies that education is a fundamental and planned endeavor to build and give birth in a learning environment to humans as learners so that students actively grow their capacity so that they have religious-spiritual force, personality, self-control as human beings with personalities, intellect, abilities, noble character that are useful to society, country, and state. Education can be interpreted as a dynamic influence in developing spiritual, physical, moral, social skills, and feelings to generate an integral person [1][12][18].

Along with globalization, information and communication technology has advanced such that information interaction and distribution can take place quickly [13][14][15]. Computer-based learning is used to function as an individual learning system. Because it works as a particular learning system, the CBI software can facilitate the learning process for individuals who use it. Therefore, CBI software development must consider the principles of learning, learning system planning, and individual learning. Students interact directly with computer-based interactive media in CBI, while teachers act as learning designers and programmers [2][3][16].

In general, the quality of education is one of the education issues that has become a priority for urgent solutions. Efforts that can be made concerning quality improvement in schools are creating a student-oriented learning system (children's center) from the various circumstances, and opportunities and promoting student needs related to learning needs that are demanding, active, imaginative, inventive, efficient, and enjoyable to create and apply knowledge and communication method learning [4][17].

Learning media includes books, tape recorders, cassettes, video cameras, video recorders, films, slides, pictures, drawings, graphics, television, and computers that are physically used to express teaching essential data. Mobile learning promotes learning where its students can access learning materials, instruction, and applications [5].

Android is an operating system designed for cellphones based on Linux, including operating systems, middleware, and open source applications. Firstly, this operating system was developed by Android Inc and was followed by Google Inc [5]. Androidbased learning media includes learning materials, video tutorials, practice questions related to digital photo composition subjects. Digital photo composition subjects are subjects in the multimedia department of vocational high schools (SMK) related to how to place various objects captured in the photo frame, whether good or not. The composition of a photo depends on the photo's needs itself. In this learning media, some materials will make it easier for students to use or choose a camera in taking image objects in digital photo composition. This is in line with what stated that multimedia packaged in interactive modules could improve student learning outcomes [6][12].

The principles of designing learning media based on Android are: (1) learning must be fun (challenging, fantasy, and curious), (2) interactivity (dynamic computer support, dynamic social support, activities, and power), and (3) training opportunities that can motivate, match and provide feedback. 


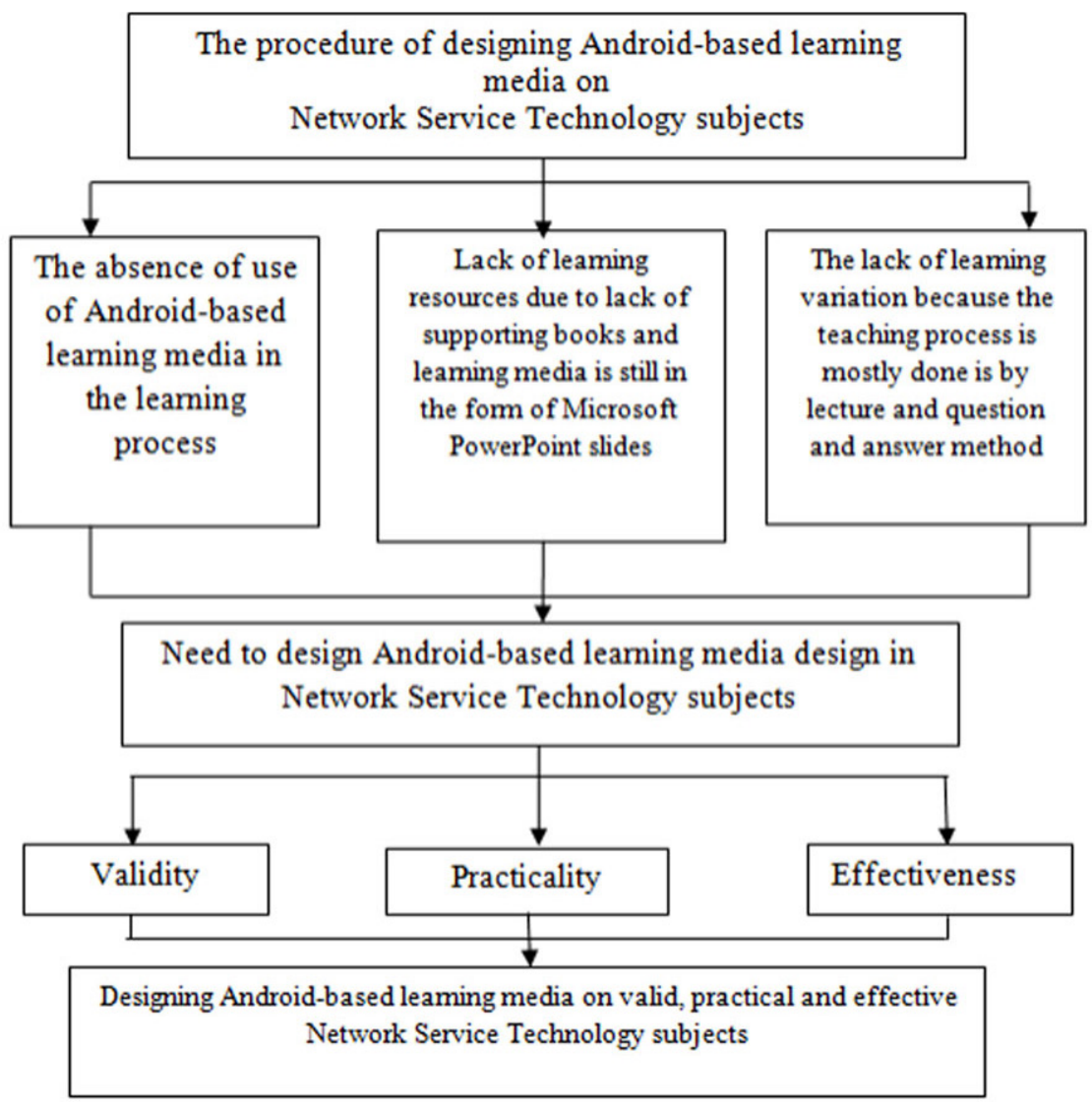

Fig. 1. Framework for research on android-based learning media design

The research objectives of this Android-based learning media are:

a. To make learning media android version as a supplement to computer assembly teaching.

b. To determine the validity, practicality, and effectiveness of Android-based learning media in the XI class network service technology subject majoring in Network Computer Engineering (TKJ) SMK Negeri 8 Padang.

\section{$2 \quad$ Method}

Styles This analysis incorporates the research and development approach usually referred to as R\&D. (Research and Development). This $R \& D$ technique is a testing method used to improve and assess the performance of particular goods. These objects 
are not typically in the shape of things or hardware, such as books, stationery, and other learning instruments. In the type of applications, however, [7].

This Adobe Optimized Runtime-based immersive learning media module was built using four-D models. Four-D development, which consists of 4 stages: identifying, planning, creating, and disseminating, relates to the media development model used [8][19].

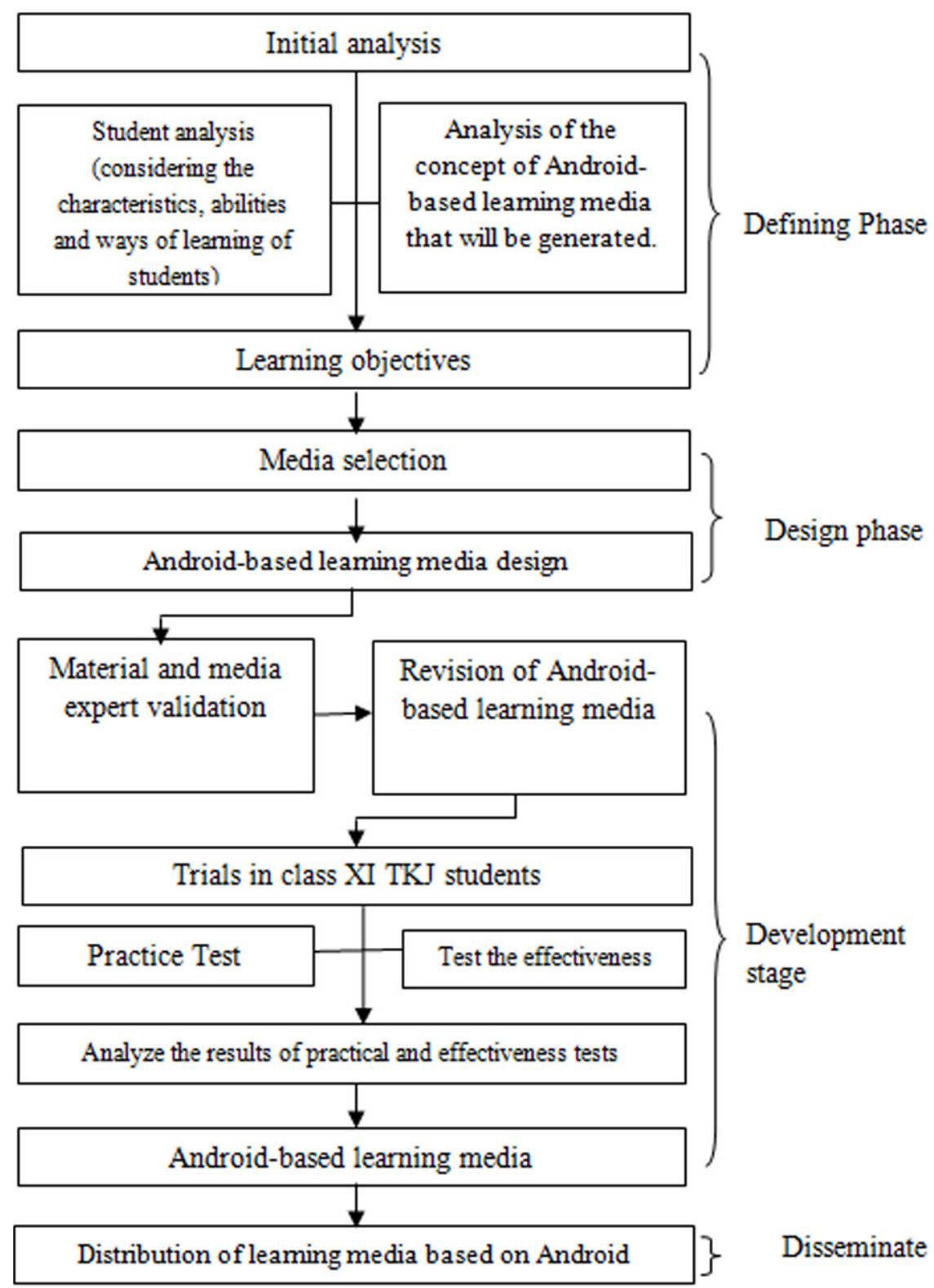

Fig. 2. Research procedure 


\subsection{Define stage (definition)}

The define stage is the stage for determining and defining the terms of learning. This definition includes several steps: preliminary analysis, student analysis, concept analysis, and the formulation/specification of learning objectives.

\subsection{Design stage (design)}

At this stage, the draft learning device is designed. In this stage, the selection of the media used and the initial product design is carried out.

\subsection{Development stage (development)}

At this stage, a revised validity, practicality, and effectiveness test were carried out based on the validator's input.

\subsection{The Disseminate stage (deployment)}

The deployment process is a final design stage. The deployment stage is carried out to promote the design product to be accepted by users, whether individuals, groups, or systems [4].

\section{Data analysis}

Using descriptive analysis, the data analysis of this research was carried out. The study involves evaluating Android-based learning media's validity, functional analysis of Android-based learning media, and analysis of Android-based learning media's efficacy [9].

\subsection{Analysis of validity test}

Validity test analysis is based on the validity test sheet, which is carried out in the following steps:

a. Provide score answers with criteria dependent on the Likert scale, namely:

Table 1. Assessment of answers

\begin{tabular}{|l|c|c|c|}
\hline \multirow{2}{*}{ Selection } & \multirow{2}{*}{ Information } & \multicolumn{2}{c|}{ Weight } \\
\cline { 3 - 4 } & & Positive & Negative \\
\hline Strongly agree & SS & 5 & 1 \\
\hline Agree & S & 4 & 2 \\
\hline Doubtful & R & 3 & 3 \\
\hline Disagree & TS & 2 & 4 \\
\hline Strongly Disagree & STS & 1 & 5 \\
\hline
\end{tabular}


b. Determines the highest score

Highest score $=$ number of validators $\times$ number of question items $\times$ maximum score.

c. Determine the overall score of each validator by summing up all the results obtained from each predictor.

d. Determine the outcome obtained by the sum of the scores of each validator.

e. The relevance meaning assessment is as follows:

$$
\mathrm{NP}=\frac{\mathrm{R}}{\mathrm{SM}} \times 100
$$

\section{Information:}

$\mathrm{NP}=$ Percent value sought or which is expected

$\mathrm{R}=$ raw score obtained by the validator

$\mathrm{SM}=$ Maximum ideal score of the test in question

$100=$ Fixed Number

f. Provide an assessment of validity with the following criteria:

Table 2. Classification of validity assessment aspects

\begin{tabular}{|l|c|l|}
\hline \multicolumn{1}{|c|}{ No } & Average value & \multicolumn{1}{c|}{ Rated aspect } \\
\hline 1 & $90 \%-100 \%$ & Very Valid \\
\hline 2 & $80 \%-89 \%$ & Valid \\
\hline 3 & $65 \%-79 \%$ & Valid Enough \\
\hline 4 & $55 \%-64 \%$ & Less Valid \\
\hline 5 & $<55 \%$ & Invalid \\
\hline
\end{tabular}

g. To find the Frequency Distribution of Validity [10] as follows:

1) Calculating the distance or range $(R)$

$\mathrm{R}=$ highest data - lowest data

2) Finding the number of classes $(\mathrm{K})$

$\mathrm{K}=1+3.3 \log$ the number of validators

3) Calculating the length of the interval class $(\mathrm{P})$

$$
\mathrm{P}=\mathrm{R} / \mathrm{K}
$$

\subsection{Practicality test analysis}

The measures to analyze the functional value of Android-based learning media are as follows:

a. Determines the highest score

Highest score $=$ number of students $\times$ number of question items $\times$ maximum score

b. Determine each student's total score by adding up

c. From each indicator, all the scores were obtained.

d. Determines the score obtained by adding up the scores of each student. 
e. Experimental test data for using Android-based learning media were analyzed using the following formula:

$$
\mathrm{NP}=\frac{\mathrm{R}}{\mathrm{SM}} \times 100
$$

\section{Information:}

$\mathrm{NP}=$ Value percent sought or expected

$\mathrm{R}=$ The raw score obtained by students

$\mathrm{SM}=$ Maximum ideal score of the test in question (number of respondents $\times$ maximum scale)

$100=$ Fixed Number

f. After the percentages are obtained, the grouping is carried out according to the following criteria:

Table 3. Practicality assessment

\begin{tabular}{|l|c|l|}
\hline \multicolumn{1}{|c|}{ No } & Score & \multicolumn{1}{c|}{ Rated aspect } \\
\hline 1 & $86 \%-100 \%$ & Very Practical \\
\hline 2 & $76 \%-85 \%$ & Practical \\
\hline 3 & $60 \%-75 \%$ & Quite Practical \\
\hline 4 & $55 \%-59 \%$ & Less Practical \\
\hline 5 & $<54 \%$ & Impractical \\
\hline
\end{tabular}

g. To find the Frequency Distribution of Practicality as follows:

1) Calculating the distance or range $(R)$

$\mathrm{R}=$ highest data - lowest data

2) Finding the number of classes $(\mathrm{K})$

$\mathrm{K}=1+3.3 \log$ number of students

3) Calculating the length of the interval class $(P)$

$\mathrm{P}=\mathrm{R} / \mathrm{K}$

\subsection{Effectiveness test analysis}

The test questions on Android-based learning media's effectiveness were obtained by calculating the scores of students who answered each item as contained in the test questions.

From this, it is analyzed by the percentage technique, which is stated by the following:

$$
\mathrm{S}=\frac{\mathrm{R}}{\mathrm{N}} \times 100 \%
$$

Information:

$\mathrm{NP}=$ expected value

$\mathrm{R}=$ The total score of the item or question that was answered correctly

$\mathrm{N}=$ Maximum Score of the test 
The results obtained are interpreted using the following criteria:

Table 4. Effectiveness assessment

\begin{tabular}{|l|c|l|}
\hline \multicolumn{1}{|c|}{ No } & Score & \multicolumn{1}{c|}{ Rated aspect } \\
\hline $\mathbf{1}$ & $86 \%-100 \%$ & Very good \\
\hline $\mathbf{2}$ & $76 \%-85 \%$ & Good \\
\hline $\mathbf{3}$ & $60 \%-75 \%$ & Pretty good \\
\hline $\mathbf{4}$ & $55 \%-59 \%$ & Less \\
\hline $\mathbf{5}$ & $\leq 54 \%$ & Very Less \\
\hline
\end{tabular}

To find the Frequency Distribution of Effectiveness as follows:

1) Calculating the distance or range $(R)$

$\mathrm{R}=$ highest data - lowest data

2) Finding the number of classes $(K)$

$\mathrm{K}=1+3.3 \log$ (number of validators)

3) Calculating the length of the interval class (p)

\section{$4 \quad$ Results and discussion}

\subsection{Intro page}

An intro page that describes the initial appearance when opening Android-based learning media.

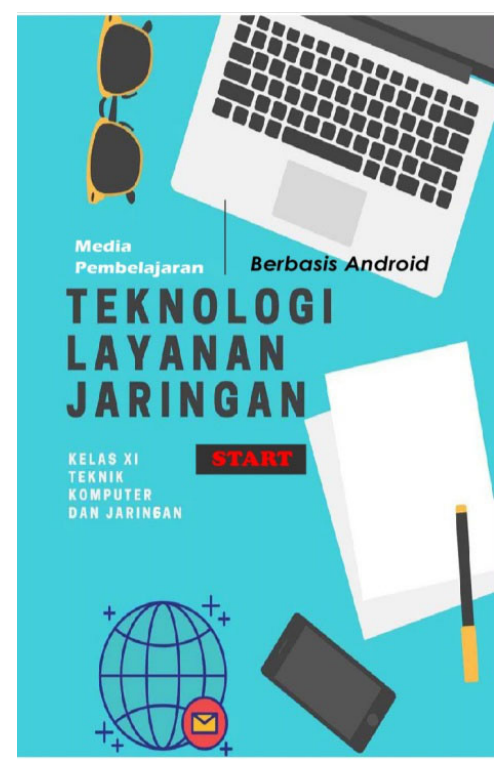

Fig. 3. Intro page 


\subsection{Main menu page}

On the page after the intro, students will enter the main page. We can see some menus that can be used in the image below:

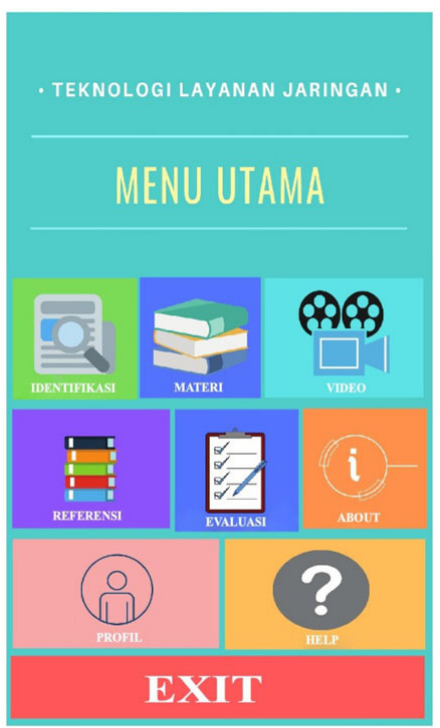

Fig. 4. Main Menu page

\subsection{Material page}

The material page will display learning material about Network Service Technology subjects equipped with competency achievement indicators and learning objectives.

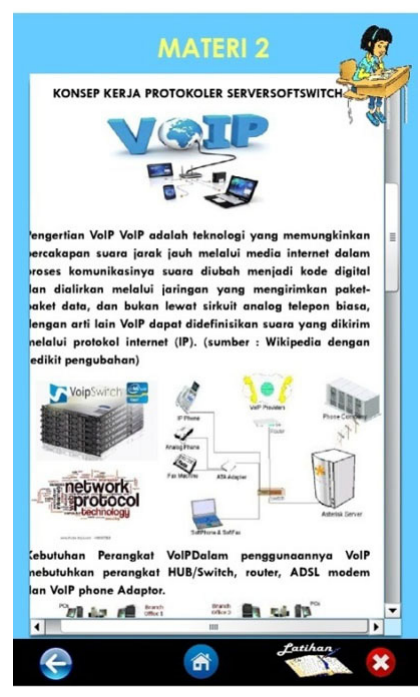

Fig. 5. Material page 


\subsection{Video page}

On this video page, a learning video of Network Service Technology material will be displayed as shown below:

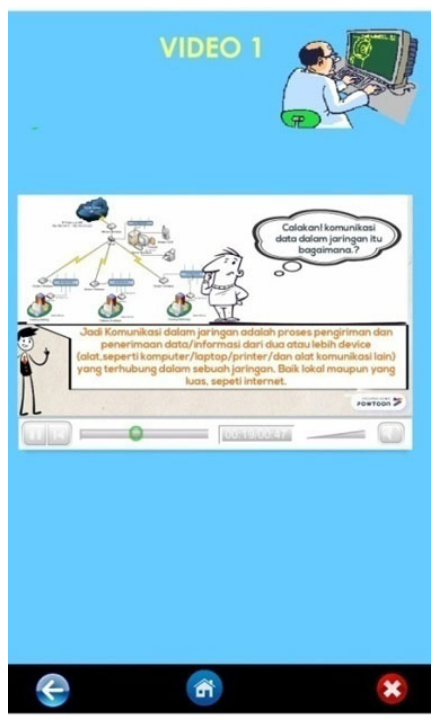

Fig. 6. Video page

\subsection{Evaluation questions page}

On the evaluation question page, the question and answer points will be displayed, as shown below:

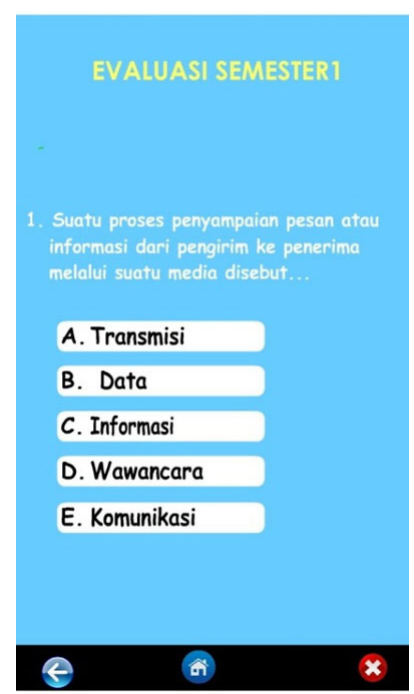

Fig. 7. Evaluation questions page 
After students have finished answering all the questions, the evaluation results' scores and scores will be displayed. A display like this is in the evaluation of semester 1 and semester 2. If you press the "repeat" button, it will be redirected back to the starting evaluation page, as shown below:

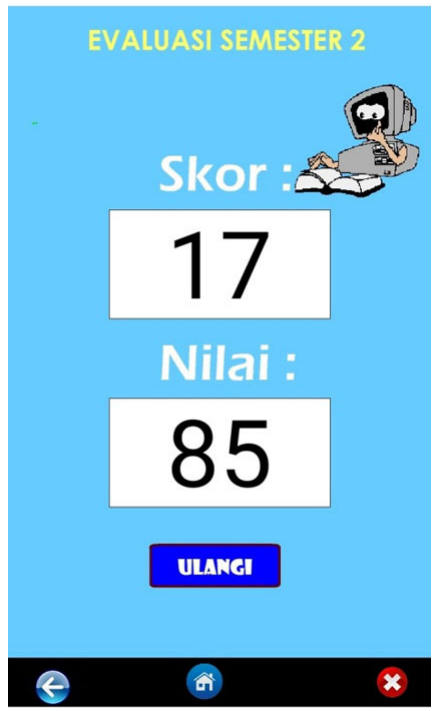

Fig. 8. Evaluation score page

\section{$5 \quad$ Analysis of validity, practicality, and effectivity}

\subsection{Analysis of validity test}

The task of the validator is to assess Android-based learning media. The validator will offer evaluation, feedback, and analysis on making Android-based learning media. The three experts validated the Android-based learning media expert by filling out the questionnaire by filling out a questionnaire on the learning media. The first and second validators were lecturers at the Faculty of Teacher Training and Education at Putra Indonesia University, "UPI YPTK" Padang. The third validator was a Teacher from Network Service Technology at SMK Negeri 8 Padang.

The evaluation of the validator for Android-based learning media, in terms of (1) Feasibility of content: $92.00 \%$; (2) Language components: $96.67 \%$; (3) parts of the presentation: 91.11\%; (4) Graphic Components 97.33\%. Overall, the validator test assessment of Android-based learning media is $94.28 \%$, so that the Android-based learning media can be said to be very valid for learning Network Service Technology.

The findings of the validator test in the use of Android-based learning media that we can see in Table 12 above are the data from the average validity score, searching for data with the following formula:

$$
\begin{aligned}
& \mathrm{NP}=\times 100 \\
& \mathrm{NP}=\times 100=94.33 \% \text { with very valid criteria }
\end{aligned}
$$


Android-based learning media's validity data through validity trials of 3 validators with 20 questions saw an average value of $92.71 \%$. It can be said that the level of validity of Android-based learning media is stated to be very valid to use for class XI in the subject of Jarnigan Service Technology in the Academic Year 2019/2020. To get a clear picture of the distribution of the validity, questionnaire scores can be seen in Table 5 and Figure 9:

Table 5. Frequency distribution of the validity questionnaire score

\begin{tabular}{|c|c|c|c|}
\hline No. & Class-Interval & F0 & F (\%) \\
\hline 1. & 93 & 1 & 33,33 \\
\hline 2. & 94 & 1 & 33,33 \\
\hline 3. & 96 & 1 & 33,33 \\
\hline & Total & 3 & 100 \\
\hline
\end{tabular}

Based on Table 5, it can be explained that the frequency distribution and level of attainment of the validator in calculating the distance or range $(R)$ are 3 ranges, the number of classes $(\mathrm{K})$ is 3 . The class length $(\mathrm{P})$ is 1 . In range 93 , there is a validator with a percentage of $33,33 \%$, in field 94 , there is one validator with a ratio of $33.33 \%$, and in the range of $96 \%$, there is one validator with a percentage of $33.33 \%$.

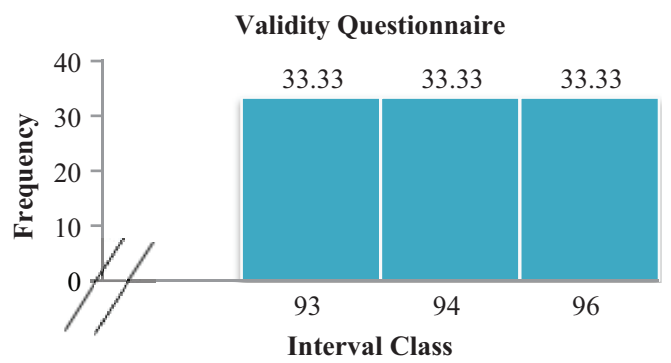

Fig. 9. Histogram of validity questionnaire

Based on Figure 9, it can be explained by the interval class length, namely 4, in range 93, there is 1 validator with a frequency of 33.33, in field 94, there is one validator with a frequency of 33.33 , and in range 96 there is one validator with a frequency of 33.33 .

\subsection{Practicality test analysis}

Practicality testing is used to determine the level of practicality of Androidbased learning media, trials conducted by 35 students. The assessed aspects consist of conditions of use, the effectiveness of learning time, and benefits comprised of 18 questions. The factors assessed in the practicality test comprised 18 statement items, namely 8 statement items for the state of use, 5 items for the statement for the effectiveness of learning time, and 5 items for benefits.

Assessment of 35 students for Android-based learning media in terms of (1) State of Use: $88.57 \%$; (2) Learning Time Effectiveness: 88.23\%; (3) Benefit: 88.57\%. Overall, the practicality test assessment for Android-based learning media was $88.46 \%$. 
The Android-based learning media could be efficient for students to use for learning Network Service Technology for class XI TKJ at SMK Negeri 8 Padang.

The results of the student practicality test using Android-based learning media search for data using the formula below:

$\mathrm{NP}=\times 100$

$\mathrm{NP}=\times 100=88.46 \%$ with very practical criteria

Experimental data of Android-based learning media through validity trials of 35 students with 18 questions saw an average value of $88.46 \%$. It can be said that the level of validity of Android-based learning media is stated to be very practical to use for class XI in Network Service Technology subjects in the Academic Year 2019/2020) [11].

Questionnaire scores can be used in Table 6 and Figure 10 to get a better view of the distribution of validity:

Table 6. Frequency distribution of questionnaire practicality scores

\begin{tabular}{|l|c|c|c|}
\hline \multicolumn{1}{|c|}{ No. } & Class-Interval & F0 & F(\%) \\
\hline 1. & $64-68$ & 4 & 11,43 \\
\hline 2. & $69-73$ & 3 & 8,57 \\
\hline 3. & $74-78$ & 7 & 20,00 \\
\hline 4. & $79-83$ & 6 & 17,14 \\
\hline 5. & $84-88$ & 12 & 34,29 \\
\hline 6. & $89-90$ & 3 & 8,57 \\
\hline & Total & 35 & 100 \\
\hline
\end{tabular}

Based on Table 6, it can be explained that the frequency distribution and level of practicality achievement in calculating the distance or range $(\mathrm{R})$ are 26 ranges, the number of classes $(K)$ is 6 . The length of the interval class $(P)$ is 4 . In the field 64-68, there are 4 respondents with a percentage of $11.43 \%$, in the range $69-73$, there were 3 respondents with a ratio of $8.57 \%$, in the field of 74-78 there were 7 respondents with a percentage of $20.00 \%$, in the range $79-83$ there were 6 respondents with a ratio of $17,14 \%$, in the range $84-88$ there are 12 with a percentage of $34.29 \%$ and in the field $89-90$ there are 3 respondents with a ratio of $8.57 \%$.

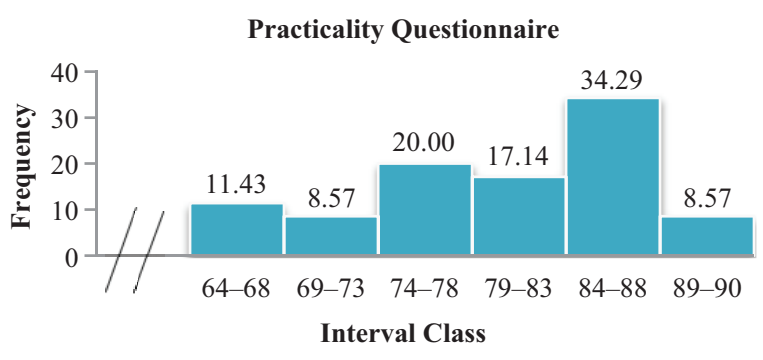

Fig. 10. Histogram for practicality questionnaire

Based on Figure 10, it can be explained by the length of the interval class, namely 6 , in the range 64-68 there are 4 respondents with a frequency of 11.43 , in the range 
69-73, there are 3 respondents with a percentage of 8.57, in the range 74-78 there are 7 respondents with frequency 20.00, in the range 79-83 there are 6 respondents with a frequency of 17.14, in the range 84-88 there are 12 respondents with a frequency of 34.29 and in the field $89-90$ there are 3 respondents with a percentage of 8.57.

\subsection{Effectiveness test analysis}

At this stage, the activity is focused on evaluating whether the Android-based learning media used is useful for increasing learning activities. The aspects that are assessed on the effectiveness test consist of 40 items.

Students very well use the assessment of 35 students for Android-based learning media for learning Network Service Technology.

The results of the student effectiveness test using Android-based learning media where the data are seen from the effectiveness value shown in the table above looking for data using the following formula:

$\mathrm{S}=\times 100$

$\mathrm{NP}=\times 100=90.86 \%$ with very good criteria

Data on Android-based learning media's effectiveness by testing the efficacy of 35 students with 40 items seen the effectiveness value of $90.86 \%$. It can be said that the level of effectiveness of Android-based learning media is stated to be very well used in the subject of Network Service Technology class XI TKJ at SMK Negeri 8 Padang in the 2019/2020 Academic Year [11].

To get a clear picture of the frequency distribution of the effectiveness test scores as in Table 7 and Figure 11:

Table 7. Frequency distribution of the effectiveness of test question scores

\begin{tabular}{|l|c|c|c|}
\hline \multicolumn{1}{|c|}{ No. } & Class-Interval & F0 & (F\%) \\
\hline 1. & $60-66$ & 2 & 5,71 \\
\hline 2. & $67-73$ & 3 & 8,57 \\
\hline 3. & $74-80$ & 4 & 11,43 \\
\hline 4. & $81-86$ & 2 & 5,71 \\
\hline 5. & $87-93$ & 2 & 5,71 \\
\hline 6. & $94-100$ & 22 & 62,86 \\
\hline & Total & 35 & 100 \\
\hline
\end{tabular}

Based on Table 10, it can be explained that the frequency distribution and level of achievement of the validator in calculating the distance or range $(\mathrm{R})$ are 40 ranges, the number of classes $(\mathrm{K})$ is 6 . The length of the interval class $(\mathrm{P})$ is 7 . In the 60-66 field, there are 2 respondents with a percentage of $5.71 \%$, in the range $67-73$, there were 3 respondents with a ratio of $8.57 \%$, in the range of 74-80 there were 4 respondents with a percentage of $11.43 \%$, in the field $81-86$ there were 2 respondents with a ratio of $5,71 \%$, in the range $87-93$ there were 2 respondents with a percentage of $5.71 \%$ and in the field $94-100$ there were 3 respondents with a ratio of $62.86 \%$. 


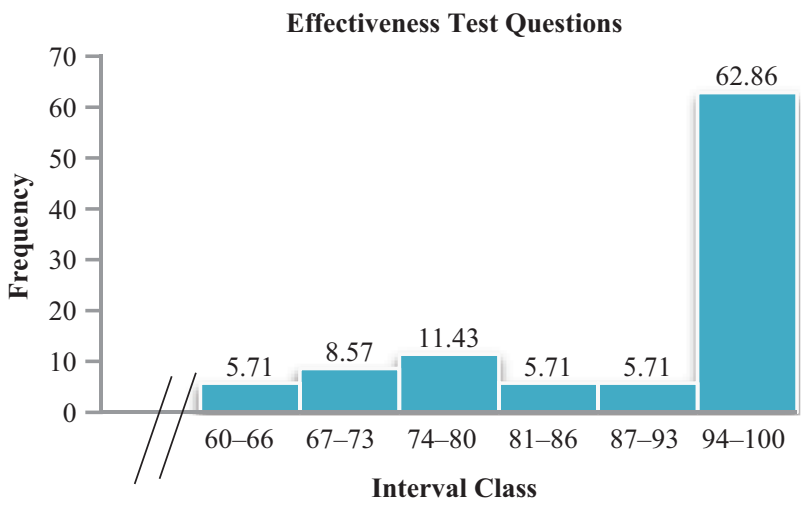

Fig. 11. Histograms for the effectiveness test

In Figure 11, it can be explained by the length of the interval class, namely 6 , in the range 60-66, there are 2 respondents with a frequency of 5.71, in the range 67-73 there are 3 respondents with a percentage of 8.57 , in the range $74-80$ there are 4 respondents with frequency 11.43 , in the range $81-86$ there are 2 respondents with a frequency of 5.71 , in the range $87-93$ there are 2 with a frequency of 5.71 and in the field $94-100$ there are 22 respondents with a frequency of 62.86 .

\section{Conclusion}

It can be inferred as follows, based on the definition, data analysis, and creation of Android-based learning media :

6.1 Validity through the validator test assessment of Android-based learning media is $94.28 \%$. The validity level can be interpreted as very valid for use in the Network Service Technology subject for class XI TKJ at SMK Negeri 8 Padang.

6.2 The practicality of Android-based learning media is $88.46 \%$. The usefulness level can be interpreted to be very practical to use in Network Service Technology class XI TKJ at SMK Negeri 8 Padang.

6.3 The effectiveness of Android-based learning media is $90.86 \%$. The significance level can be interpreted to be very well used in Network Service Technology class XI TKJ at SMK Negeri 8 Padang.

In the use of learning media to support better learning, the following are suggested: 1) It is better if teachers are required to be able to create learning media that can generate learning interest, which can affect satisfactory student learning outcomes and by learning objectives, because From the research obtained by the author, currently, middle-level students do not like learning more, students feel bored, bored and not interested in learning. This is caused by several factors such as the absence of attractive learning media, lack of interest and motivation to learn, and inadequate facilities and infrastructure. 2) For policymakers in education, it is recommended that they provide a source of funds, facilities and infrastructure, and other facilities so that educational goals can be adequately conveyed, learning activities in class are maximized, and the 
holding of training to improve teacher professionals so that they can be more creative in delivering learning.

\section{$7 \quad$ References}

[1] Chomaidi dan Salamah. (2018). Pendidikan dan Pengajaran. Jakarta: PT. Grasindo.

[2] Rusman. (2012). Belajar dan Pembelajaran Berbasis Komputer. Bandung: Alfabeta.

[3] Arsyad. (2016). Media Pembelajaran. Jakarta: PT Raja Grafindo.

[4] Prasetyo, H., Kristiyanto, A. and Doewes, M. (2019). The development of Android-based mobile learning media in healthy lifestyle teaching materials for senior high school students. International Journal of Multicultural and Multireligious Understanding, 6(2), 188-194. https://doi.org/10.18415/ijmmu.v6i2.656

[5] Hasyim, N., Gani, H.A. and Hatta, S. (2020). Android Based Multimedia Learning for VocationalHighSchools. Journal ofEducational ScienceandTechnology(EST), 6(2), 193-204. https://doi.org/10.26858/est.v6i2.14275

[6] Wijaya, I. and Sefriani, R. (2017). Interactive modules based adobe director on computer assembling subjects for vocational secondary school students. VOLT: Jurnal Ilmiah Pendidikan Teknik Elektro, 2(2), 73-80. https://doi.org/10.30870/volt.v2i2.2116

[7] Sugiyono. (2013). Metode Penelitian Pendidikan (Pendekatan Kuantitati, Kualitatif dan R\&D). Bandung: Alfabeta.

[8] Thiagarajan, dkk. (1974). Instructional Development for Training Teachers of Exceptional Children. Minneapolis, Minnesota: Leadership Training Institute/ Special Education, University of Minnesota. https://bustangbuhari.wordpress.com/2011/08/25/four-d-modelmodel-pengembangan-perangkat-pembelajaradari-Thiagarajan-dkk.diakses $\quad$ 10/10/2019 pukul 19.44 wib

[9] Purwanto, Ngalim. (2010). Prinsip-Prinsip dan Teknik Evaluasi Pengajaran. Bandung: PT Remaja Rosdakarya.

[10] Sugiyono. (2013). Metode Penelitian Pendidikan (Pendekatan Kuantitati, Kualitatif dan R\&D). Bandung: Alfabeta

[11] Irianto, A, (2014). Statistik: Konsep Dasar, Aplikasi, dan Pengembangannya, Edisi Kedua. Jakarta: Kencana Prenadamedia Group.

[12] Krismadinata, U.V., Jalinus, N., Rizal, F., Sukardi, P.S., Ramadhani, D., Lubis, A.L., Friadi, J., Arifin, A.S.R. and Novaliendry, D. (2020). Blended Learning as Instructional Model in Vocational Education: Literature Review. Universal Journal of Educational Research, 8(11B), 5801-5815. https://doi.org/10.13189/ujer.2020.082214

[13] Cheng-Hong, Y., Novaliendry, D., Jin-Bor, C., Renyaan, A.S., Lizar, Y., Guci, A., Ariyon, M., Ramadhani, D., Verawardina, U., Desnelita, Y. and Susanti, W. (2020). Prediction of Mortality in the Hemodialysis Patient with Diabetes using Support Vector Machine. Revista Argentina de Clínica Psicológica, 29(4), 219. https://doi.org/10.24205/03276716.2020.823

[14] Novaliendry, D., Wattimenac, F.Y., Renyaan, A.S., Lubis, A.L., Ramadhani, D., Lizar, Y. and Guci, A. (2020). Development of an Expert System Application to Detect Vitamin Deficiencies in the Human Body. International Journal of Early Childhood Special Education (INT-JECSE), 29(5), p. 956. https://doi.org/10.24205/03276716.2020.1092

[15] Novaliendy, D., Hendriyani, Y., Yang, C.H. and Hamimi, H. (2015). The optimized K-means clustering algorithms to analyzed the budget revenue expenditure in Padang. Proceeding of the Electrical Engineering Computer Science and Informatics, 2(1), pp. 61-66. https://doi. org/10.11591/eecsi.v2i1.771

[16] Novaliendry, D., Adri, M., Sriwahyuni, T., Huda, A., Huda, Y., Irfan, D., Jaya, P., Ramadhani, D. and Anori, S., Development of Smart Learning Media Model Based on Android. 
[17] O’Bryan, A., Compton, L., Gutiérrez, J.D. and Payne, T. (2019). Scaffolding Successful Mobile Experiences for Frontline ESL Workers: An Exploratory Study. Int. J. Adv. Corp. Learn., 12(3), 24-32. https://doi.org/10.3991/ijac.v12i3.11182

[18] Friedl, M., Ebner, M. and Ebner, M. (2020). Mobile learning applications for android und iOS for German language acquisition based on learning analytics measurements. Int. J. Learn. Anal. Artif. Intell. Educ. IJAI, 2(1), p. 4. https://doi.org/10.3991/ijai.v2i1.12317

[19] Ismail, A., Zaharuddin, R., Hashim, N. and Ariffin, J. (2020). The Impact of e-NPQEL on the Continuance Intention of Using e-Training among Aspired School Leaders in Malaysia. https://doi.org/10.3991/ijim.v14i19.15965

\section{Authors}

Dony Novaliendry, S.Kom., M.Kom., Currently in the completion stage of S3 at the National Kaohsiung University of Science and Technology (NKUST) in Taiwan in the field of Bio-Informatics. Currently interested in developing themselves in the fields of bio-informatics, bio-medics, Artificial Intelligence, Decision Support System, Multimedia, Big Data and Data Mining. Email address: dony.novaliendry@ft.unp.ac.id

Dr. Asrul Huda, S.Kom., M.Kom is currently working at, Universitas Negeri Padang. Indonesia, as Senior Lecturer. Experienced in Technical Vocational Education and Training, especially in Electrical Engineering, since 2010 until now. Currently has a degree of Doctorate in Universitas Negeri Padang. Indonesia. Research interest includes TVET, Multimedia Graphic Design, Educational research. Having 17 Publications in Journals. Completed 15 projects and has a vast experience in the field of Multimedia and graphic design. asrulhuda@gmail.com

Debi Sanita, Currently pursuing a Masters in Engineering Education (M.Pd. T) at the Faculty of Engineering, Padang State University, with a major in Information Engineering and Computer Education in the Technology and Vocational Education Study Program, besides that he is also active in the Kayu Aro West Sumatra Student and Student Association (IPMKA SUMBAR) as the Organizational Advisory Council (DPO). Email address: debisanita@outlook.com.

Dino Adi Putra, Born in Painan, November 5, 1996, completed a Bachelor of Education (S.Pd) at the Pesisir Selatan Teaching College (STKIP) in 2019. and is currently pursuing Masters Education at Padang State University in the Faculty of Engineering with major Technology and Vocational Education, Currently serving as a Lecturer at one of the Pesisir Selatan Teaching Colleges for Education (STKIP), besides that he is also active now in a career in the Youtube Creator field, the author can be contacted via email dinoadiputra05@gmail.com.

Marsinah Dewi Feiyska Nasution, is an IT Contract Education Staff at the State University Padang from 2019 to the present. Then in the new academic year 2020, the author continued his master's study at the Technological and Vocational Education Study Program, Faculty of Engineering, Padang State University, which he undertook while working. The author can be contacted at e-mail address feiyskanasution@, unp.ac.id

Rezi Septiardi Putra, Born in Air Haji, September 9, 1993, completed his Bachelor of Education (S. Pd) at Putra Indonesia University YPTK Padang in 2016. And is currently pursuing Masters Education at Padang State University in the Faculty of Engineering with the Department of Technology and Vocational Education, currently 
serving as staff in the West Sumatra Provincial DPRD, the author can be contacted via e-mail rseptiardi93@gmail.com.

Rizka Novri Hidayati, Majoring in informatics and computer engineering education graduated in 2018 with a final project entitled "Development of Web-Based Outdoor Equipment Rental Information Systems". After earning a bachelor's degree in education, the author continued his Masters education in the Department of Technology and Vocational Education, Padang State University until now and is still a postgraduate student. The author is now doing culinary entrepreneurship with her husband while continuing his postgraduate education. The author can be contacted via email: rizkanovrihidayati27@gmail.com or at the following address. University Address: Technology and Vocational Education Program at Padang State University, Jl. Prof. Dr. Hamka, Air Tawar Bar., Kec. Padang Utara, Kota Padang, West Sumatra 25171, Telephone (0751) 7053902. Home address: Gurun Laweh RT 03 RW 02 No.1, Gurun Laweh Nanggalo, Padang City, Telephone/Hp. 082268111100.

Article submitted 2021-05-05. Resubmitted 2021-07-02. Final acceptance 2021-07-02. Final version published as submitted by the authors. 